\title{
Effect of Different Culture Media on Growth and Sporulation of Alternaria brassicae Incident of Alternaria blight of Mustard
}

\author{
Ashwini Kumar* and S.N. Singh \\ Department of Plant Pathology, Jawaharlal Nehru Krishi Viswa Vidyalaya, Jabalpur, \\ Madhya Pradesh, India \\ *Corresponding author
}

\section{A B S T R A C T}

\begin{tabular}{|l|}
\hline Ke y w or d s \\
Culture media, $A$. \\
brassicae, Growth, \\
Sporulation
\end{tabular}

Keywords

Culture media, $A$. brassicae, Growth,

\section{Introduction}

Rapeseed-mustard group is one of the important oilseed crops cultivated in India. India ranks first both in area and production of rapeseed and mustard in Asia (Anon, 2012). Mustard (Brassica juncea (L.) Czern \& Coss.) is cultivated in an area of 6.70 million ha with a production of $7.96 \mathrm{mt}$ and productivity of $1188 \mathrm{~kg} / \mathrm{ha}$. Rajasthan, Uttar Pradesh and Madhya Pradesh are the major rapeseed and mustard growing states in India. The production and productivity of rapeseed and mustard are hampered due to different biotic and abiotic challenges faced by the crop.
Among various biotic factors, Alternaria blight caused by $A$. brassicae has been reported universally from all the continents of the world and thus omnipresent in nature.

Alternaria affects most cruciferous crops, including broccoli and cauliflower, field mustard and turnip, leaf or Chinese mustard, Chinese or celery cabbage, cabbage, rape, and radish. Hence, $A$. brassicae and $A$. brassicicola are cosmopolitan in their distribution. Symptoms of both these diseases on same leaves are quite common, while, combined infection of downy mildew and white rust on mustard have been observed 
rarely. Alternaria blight causes up to 47 per cent yield loss in mustard (Meena et al., 2010) with no proven source of resistance till date. A. brassicae usually sporulate poorly, and provide slow mycelial growth in common media particularly Potato Dextrose Agar (Meena et al., 2012). A. brassicae is sensitive to nutritional and environmental factors and thus its growth and sporulation is influenced by composition of the nutrient media. Therefore, present study was carried out using a set of 20 different isolates of Alternaria brassicae from mustard for their preferential selectivity on eight different media to obtain better growth and sporulation.

\section{Materials and Methods}

\section{Collection, isolation and purification of disease sample}

During Dec.- Jan., of 2015-17 survey was conducted in mustard growing areas and markets of different divisions of Madhya Pradesh including Gwalior, Morena, Bhind, Datia, Sheopur and Shivpuri etc. and it was observed that there is severe infection of Alternaria blight in mustard. Special emphasis was given for occurrence and study of symptoms of the disease during different stages of plant growth at JNKVV, College of Agriculture, Jabalpur. Alternaria brassicae culture was isolated from diseased mustard plant showing concentric ring like symptoms on leaves from different areas. Isolates were identified microscopically by their characteristic shape of conidia. Isolates of the pathogen were maintained in culture tubes containing PDA medium and used as stock culture of the target organism throughout the study.

The leaves of affected mustard plants showing typical symptoms of Alternaria blight were cut (sterilized scalpel) and isolation were made for the presence or absence of the causal organism. These selected infected spots were washed 3-4 times in sterilized distilled water followed by surface sterilization by dipping in $4 \% \mathrm{NaOCl}$ solution for $1 \mathrm{~min}$, followed by washing with sterilized water 3-4 times. Surface sterilized pieces were then aseptically transferred into $9 \mathrm{~cm}$ Petri dishes containing Potato Dextrose Agar (PDA) and incubated at $25 \pm 2{ }^{\circ} \mathrm{C}$ for seven days. Thereafter, growing mycelia from margin of apparently distinct colonies of the leaf spot pieces were aseptically transferred into another Petri plate containing PDA medium, where it was grown for 15 days at $23 \pm 2{ }^{\circ} \mathrm{C}$ in the BOD incubator. On the basis of their conidiophore and conidial morphology as described by Simmons (2007), the pathogen was identified as Alternaria brassicae (Berk.) Sacc. and purified by single spore isolation method. The culture was preserved in the refrigerator $\left(4^{\circ} \mathrm{C}\right)$ for further studies. The detailed location and coding of the isolates has been presented in table 1 .

\section{Results and Discussion}

All the eight tested media significantly supported the growth of $A$. brassicae. However, isolates showed selectivity for its growth on different tested media. The maximum mycelia growth of $88.33 \mathrm{~mm}$ was attained on mustard leaf extract. Average mycelia growth of 20 isolates ranged from $32.28 \mathrm{~mm}$ (Carrot Agar medium) to $76.10 \mathrm{~mm}$ on mustard leaf extract medium. Among the 20 different isolates, one isolate named I13 showed maximum mycelia growth of $87.0 \mathrm{~mm}$ and $88.3 \mathrm{~mm}$ on PDA and mustard leaf extract medium respectively. However, on other media different isolates showed different preferential reactions for its mycelia growth. One isolate namely $\mathrm{I} 12$ was recorded as slowest in its mycelia growth on four different media namely PDA $(50.0 \mathrm{~mm})$, Mustard leaf extract $(55.3 \mathrm{~mm})$, Cabbage leaf extract (38.6 $\mathrm{mm}$ ) and cauliflower leaf extract media 931.3 
$\mathrm{mm})$. However isolate I18 showed least mycelia growth on Corn meal Agar (36.3 $\mathrm{mm})$, Czepexdox Agar $(45.3 \mathrm{~mm})$ and Rose Bengal Agar medium $(38.0 \mathrm{~mm})$. This showed significant variability among the 20 tested isolates of $A$. brassicae and their preferential selectivity in utilizing the media for their growth. The detailed data of 20 isolates of $A$. brassicae on eight different media have been presented in table 2 .

Based on their growth on different media, the isolates were categorized into four classes including poor, slow, good and abundant growth type. It was observed that maximum number of 11 isolates could be categorized under abundant growth type class on Mustard leaf extract media. This was followed by 8 isolates on PDA showing abundant growth. In total, 9 and 7 isolates were grouped under good growth type class on PDA and mustard leaf extract medium. Further, all the 20 isolates showed poor type growth on Carrot agar medium. This was followed by 19 isolates of poor growth type on Capexdox agar medium. It was observed that $100 \%$ isolates fell into either poor or moderate mycelia growth type class on all the media except PDA and mustard leaf extract medium. Among the 20 different isolate one isolate showed poor and moderate growth on PDA. However, on mustard leaf extract, only two isolates showed moderate type mycelia growth. This indicated, the PDA and mustard leaf extract medium to be better growth supporting media for $A$. brassicae. The grouping of all the 20 isolates of $A$. brassicae falling in different classes of mycelia growth has been presented in table 3 .

Table.1 List of Alternaria brassicae isolates collected from different locations

\begin{tabular}{|c|c|c|c|c|c|}
\hline S. No. & District & Location & Previous crop & Variety & Isolates code \\
\hline \multirow[t]{2}{*}{1.} & Gwalior & Gwalior & Bajra & Varuna & $\mathrm{I}_{1}$ \\
\hline & & Bhitarwar & Jowar & Rohini & $\mathrm{I}_{2}$ \\
\hline \multirow[t]{4}{*}{2.} & Morena & Morena & Bajra & Varuna & $\mathrm{I}_{3}$ \\
\hline & & Abhah & Bajra & NRC-2 & $\mathrm{I}_{4}$ \\
\hline & & Porsa & Jawar & Kranti & $\mathrm{I}_{5}$ \\
\hline & & Joura & Bajra & Kranti & $\mathrm{I}_{6}$ \\
\hline \multirow[t]{5}{*}{3.} & Bhind & Bhind & Jawar & JM -3 & $\mathrm{I}_{7}$ \\
\hline & & Lahar & Urd & JM -3 & $\mathrm{I}_{8}$ \\
\hline & & Gohad & - & JM-3 & $\mathrm{I}_{9}$ \\
\hline & & Atair & sesame & Urvasi & $\mathrm{I}_{10}$ \\
\hline & & Mehgoan & Bajra & Arpan & $\mathrm{I}_{11}$ \\
\hline \multirow[t]{3}{*}{4.} & Datia & Datia & Sesame & Varuna & $\mathrm{I}_{12}$ \\
\hline & & Seondha & - & Varuna & $\mathrm{I}_{13}$ \\
\hline & & Bhander & Sesame & Varuna & $\mathrm{I}_{14}$ \\
\hline \multirow[t]{3}{*}{5.} & Sheopur & Sheopur & Urd & NRC-2 & $\mathrm{I}_{15}$ \\
\hline & & Karahal & Soybean & JM-3 & $\mathrm{I}_{16}$ \\
\hline & & Vijaypur & - & Varuna & $\mathrm{I}_{17}$ \\
\hline \multirow[t]{2}{*}{6.} & Shivpuri & Pohri & - & Kranti & $\mathrm{I}_{18}$ \\
\hline & & Karera & Urd & Varuna & $\mathrm{I}_{19}$ \\
\hline 7. & Jabalpur & Jabalpur & Soybean & Pusa bold & $\mathrm{I}_{20}$ \\
\hline
\end{tabular}


Int.J.Curr.Microbiol.App.Sci (2018) 7(5): 3334-3340

Table.2 Effect of different media on mycelial growth of 20 isolates Of Alternaria brassicae

\begin{tabular}{|c|c|c|c|c|c|c|c|c|}
\hline \multirow[t]{2}{*}{ Isolate } & \multicolumn{8}{|c|}{ Mycelial growth (mm) 12 days after inoculation } \\
\hline & $\begin{array}{c}\text { Potato } \\
\text { dextrose } \\
\text { agar }\end{array}$ & $\begin{array}{c}\text { Mustard } \\
\text { leaf } \\
\text { extract }\end{array}$ & $\begin{array}{c}\text { Cabbage } \\
\text { extract }\end{array}$ & $\begin{array}{c}\text { Caulifl } \\
\text { ower } \\
\text { extract }\end{array}$ & $\begin{array}{l}\text { Carrot } \\
\text { agar }\end{array}$ & $\begin{array}{l}\text { Corn } \\
\text { meal } \\
\text { agar }\end{array}$ & $\begin{array}{l}\text { Czapex } \\
\text { dextrose }\end{array}$ & $\begin{array}{c}\text { Rose } \\
\text { Bengal } \\
\text { agar }\end{array}$ \\
\hline $\mathrm{I}_{1}$ & 81.3 & 81.6 & 45.3 & 42.0 & 39.3 & 40.6 & 25.3 & 35.0 \\
\hline $\mathrm{I}_{2}$ & 85.0 & 86.3 & 51.3 & 35.6 & 30.6 & 39.6 & 31.6 & 43.6 \\
\hline $\mathrm{I}_{3}$ & 80.0 & 80.6 & 38.6 & 41.3 & 34.3 & 43.6 & 36.0 & 35.3 \\
\hline $\mathrm{I}_{4}$ & 75.0 & 77.0 & 52.3 & 35.3 & 38.6 & 48.6 & 40.6 & 41.3 \\
\hline $\mathrm{I}_{5}$ & 74.0 & 75.3 & 58.6 & 51.3 & 25.6 & 54.6 & 37.6 & 45.3 \\
\hline $\mathrm{I}_{6}$ & 76.0 & 78.0 & 55.3 & 41.6 & 33.3 & 44.6 & 51.6 & 35.6 \\
\hline $\mathrm{I}_{7}$ & 72.0 & 74.3 & 53.6 & 38.6 & 43.0 & 37.3 & 35.0 & 45.6 \\
\hline $\mathrm{I}_{8}$ & 69.6 & 71.0 & 48.6 & 40.6 & 40.6 & 39.3 & 31.3 & 51.6 \\
\hline $\mathrm{I}_{9}$ & 55.3 & 60.6 & 54.0 & 44.3 & 35.6 & 52.3 & 41.3 & 52.3 \\
\hline$I_{10}$ & 70.0 & 72.3 & 50.3 & 52.0 & 31.3 & 47.6 & 49.0 & 53.6 \\
\hline $\mathrm{I}_{11}$ & 71.0 & 72.0 & 45.3 & 41.3 & 26.3 & 47.0 & 26.0 & 35.3 \\
\hline $\mathrm{I}_{12}$ & 50.0 & 55.3 & 38.6 & 31.3 & 32.0 & 45.0 & 22.6 & 38.0 \\
\hline $\mathrm{I}_{13}$ & 87.0 & 88.3 & 52.0 & 48.6 & 27.6 & 41.0 & 31.6 & 35.3 \\
\hline $\mathrm{I}_{14}$ & 80.0 & 83.6 & 55.6 & 48.0 & 36.6 & 43.6 & 43.0 & 38.3 \\
\hline $\mathrm{I}_{15}$ & 78.0 & 78.3 & 45.6 & 41.3 & 38.0 & 49.6 & 30.0 & 34.0 \\
\hline $\mathrm{I}_{16}$ & 85.0 & 86.3 & 50.0 & 52.0 & 34.3 & 50.6 & 29.0 & 40.6 \\
\hline $\mathrm{I}_{17}$ & 83.0 & 84.3 & 55.6 & 56.3 & 25.0 & 50.0 & 38.3 & 45.0 \\
\hline $\mathrm{I}_{18}$ & 73.0 & 75.3 & 59.3 & 52.0 & 26.6 & 36.3 & 45.3 & 38.0 \\
\hline $\mathrm{I}_{19}$ & 75.0 & 76.3 & 58.3 & 52.6 & 23.6 & 39.0 & 22.3 & 31.3 \\
\hline $\mathrm{I}_{20}$ & 62.0 & 65.3 & 51.3 & 46.3 & 23.3 & 42.0 & 22.6 & 37.3 \\
\hline Avg.. & 74.11 & 76.10 & 50.98 & 44.62 & 32.28 & 44.62 & 34.50 & 40.63 \\
\hline Sem \pm & 0.2 & 0.3 & 0.4 & 0.5 & 0.5 & 0.5 & 0.6 & 0.6 \\
\hline $\begin{array}{l}\text { CD at } \\
5 \%\end{array}$ & 0.5 & 1.0 & 1.4 & 1.6 & 1.5 & 1.5 & 1.9 & 1.7 \\
\hline
\end{tabular}

Table.3 Categorization based on rate of mycelial growth

\begin{tabular}{|c|c|c|c|c|c|c|c|c|}
\hline Category & PDA & MLE & CBLE & CLE & CA & CMA & CzDA & RBA \\
\hline 0 & 1 & 00 & 8 & 14 & 20 & 18 & 19 & 17 \\
\hline$I$ & 1 & 2 & 12 & 06 & 00 & 02 & 01 & 03 \\
\hline$\|$ & 9 & 7 & 00 & 00 & 00 & 00 & 00 & 00 \\
\hline$I I$ & 9 & 11 & 00 & 00 & 00 & 00 & 00 & 00 \\
\hline
\end{tabular}

Category - 0 (Poor), Category-I (Moderate), Category- II (Good), Category- III (Abundant) 
Table.4 Effect of different media on sporulation of 20 isolates of Alternaria brassicae

\begin{tabular}{|c|c|c|c|c|c|c|c|c|}
\hline Isolate & PDA & MLE & CBLE & CLE & CA & CMA & CZDA & RBA \\
\hline $\mathrm{I}_{1}$ & ++ & +++ & +++ & ++ & ++ & + & ++ & ++ \\
\hline $\mathrm{I}_{2}$ & ++ & +++ & ++ & ++ & ++ & + & + & + \\
\hline $\mathrm{I}_{3}$ & ++ & +++ & ++ & ++ & ++ & + & + & + \\
\hline $\mathrm{I}_{4}$ & ++ & ++++ & ++ & +++ & ++ & - & + & ++ \\
\hline $\mathrm{I}_{5}$ & ++ & ++ & ++ & ++ & - & + & + & ++ \\
\hline $\mathrm{I}_{6}$ & ++ & +++ & +++ & ++ & ++ & ++ & + & + \\
\hline $\mathrm{I}_{7}$ & ++ & ++ & +++ & ++ & + & + & ++ & + \\
\hline $\mathrm{I}_{8}$ & ++ & +++ & ++ & ++ & + & - & + & ++ \\
\hline $\mathrm{I}_{9}$ & ++ & +++ & ++ & ++ & - & + & + & + \\
\hline $\mathrm{I}_{10}$ & +++ & +++ & ++ & ++ & + & + & + & + \\
\hline $\mathrm{I}_{11}$ & + & +++ & ++ & ++ & + & + & + & + \\
\hline $\mathrm{I}_{12}$ & +++ & +++ & ++ & ++ & + & - & + & + \\
\hline $\mathrm{I}_{13}$ & +++ & +++ & ++ & +++ & + & + & + & ++ \\
\hline $\mathrm{I}_{14}$ & ++ & +++ & ++ & ++ & + & + & ++ & + \\
\hline $\mathrm{I}_{15}$ & +++ & +++ & ++ & ++ & - & ++ & + & + \\
\hline $\mathrm{I}_{16}$ & ++ & +++ & ++ & +++ & + & + & + & ++ \\
\hline $\mathrm{I}_{17}$ & ++ & +++ & ++ & ++ & + & - & + & + \\
\hline $\mathrm{I}_{18}$ & ++ & +++ & ++ & ++ & + & + & + & + \\
\hline $\mathrm{I}_{19}$ & ++ & ++ & ++ & ++ & - & + & + & + \\
\hline $\mathrm{I}_{20}$ & ++ & ++ & ++ & ++ & + & - & + & ++ \\
\hline+++ & ++ & ++ & ++ & ++ & ++ & + & + & + \\
\hline
\end{tabular}

$++++=>30$ conidia per microscopic field $+++=20-30$ conidia pr microscopic field $++=10-20$ conidia per microscopic field $+0-10$ conidia per microscopic field - = no sporulation 
All the 20 isolates were sporulating on all the tested media except few isolates which were recorded as non-sporulating on carrot agar and Corn meal Agar medium. The degree of sporulation varied from isolate to isolate and media to media. However, most of the isolates produced abundant conidia on potato dextrose agar and mustard leaf extract medium. The conidial count for different isolates per microscopic field on different media has been presented in table 4.

Kumar and Singh (2003) and Singh et al., (2015) conducted their studies on A. brassicae and they observed that there was presence of profuse variability among the isolates of $A$. brassicae on different media with respect to cultural and morphological characterization. They recorded that mycelia growth of $A$. brassicae was best supported by PDA followed by Radish dextrose agar and Brassica leaf extract agar media. The results obtained in present findings are in same fashion. However, Selvamani et al., (2013) observed that Cauliflower Leaf Extract Agar was the best medium followed by Potato Dextrose Agar for mycelia growth. Mehra et al., (2017) tested eight different nutrient media which also evidenced for variation in the radial growth of twenty different $A$. brassicae isolates as in the present finding.

The results of present findings are in confirmation with Shakya, 2012 who reported that mustard Leaf Agar medium was more appropriate for the culture of Alternaria blight pathogen over three tested media. Ansari et al., (1988) reported that Alternaria brassicae sporulates well on range of media but maximum growth was recorded in PDA.

Mehta and Sangwan (2003) reported that Mustard Leaf Extract media was most favoring media for growth and sporulation of A. brassicae which are in same line as per results of present findings.

\section{Acknowledgement}

Authors are thankful to Professor and Head, Department of Plant Pathology for providing facilities for conducting the present research work.

\section{References}

Anonymous. 2012. Mustard reports of higher sowing may pressurize price but winter demand to support prices during off season. Mustard updates. Angel Broking, Mumbai, India: $4 \mathrm{p}$

Ansari, N.A., Khan, M.W. and Muheet, A. 1988. Identify and cultural characters of the pathogen causing Alternaria blight of rapeseed and mustard. J. Oilseeds Res. 5: 33-39.

Kumar P. and Singh D.V. 2003. Effect of nutrient media on growth of Alternaria brassicae. J Mycol Res 41: 101-102.

Meena P.D., Awasthi R.P., Chattopadhyay C., Kolte S.J. and Kumar Arvind. 2010. Alternaria blight: a chronic disease in rapeseed-mustard. Journal of Oilseed Brassica 1(1): 1-11

Meena P.D., Rani A, Meena R., Sharma P., Gupta R. and Chowdappa P. 2012. Aggressiveness, diversity and distribution of Alternaria brassicae isolates infecting oilseed Brassica in India. African J Microbiol Res 6: 52495258.

Mehra Prateeksha, Tewari A.K. and Taj Gohar. (2017). Studies on cultural, morphological, pathogenic and molecular variability of Alternaria brassicae, the causal agent of blight disease of rapeseed-mustard. Journal of seed Brassica, 8 (2): 106-119, July 2017

Mehta, N., Sangwan, M.S. and Srivastava, M. P. 2003. Morphological and Pathological variations in rapeseed and mustard isolates of Alternaria 
brassicae. Ind Phytopathol 56(2): 188190

Selvamani R., Prakasa Pandian R.T. and Sharma P. 2013. Morphological and cultural diversity of Alternaria brassicae (Berk.) Sacc. Isolates cause of black leaf spot of Crucifers. Ann Pl Protec Sci 21: 337-341.

Simmons E.G. 2007. Alternaria: "An Identification Manual", CBS Fungal
Biodiversity Center, Series No. 6, Utrecht. The Netherland: 775pp.

Singh M., Singh H.K., Singh R.B., Shiwangi and Abhishek. 2015. Cultural and pathogenic variability in Alternaria brassicae isolates of Indian mustard [Brassica juncea (L.) Czern. \& Coss.] collected from different agro-climatic regions of India. Res Environ Life Sci 8: 281-286.

\section{How to cite this article:}

Ashwini Kumar and Singh, S.N. 2018. Effect of Different Culture Media on Growth and Sporulation of Alternaria brassicae Incident of Alternaria blight of Mustard. Int.J.Curr.Microbiol.App.Sci. 7(05): 3334-3340. doi: https://doi.org/10.20546/ijcmas.2018.705.389 